\title{
DYNAMICS OF LAND COVER CHANGES AND DELINEATION OF GROUNDWATER RECHARGE POTENTIAL SITES IN THE AGUANAVAL AQUIFER, ZACATECAS, MEXICO
}

\author{
GONZÁLEZ-TRINIDAD, J. - JÚNEZ-FERREIRA, H. E. * - PACHECO-GUERRERO A. - \\ OLMOS-TRUJILLO, E. - BAUTISTA-CAPETILLO, C. F.
}

\author{
Maestría en Ingeniería Aplicada con Orientación en Recursos Hidráulicos, Universidad \\ Autónoma de Zacatecas, Av. Ramón López Velarde No. 801, Zacatecas, Zacatecas, C.P. 98000, \\ México (tel: + 492-924-2432; fax: +492-925-6690 ext.1613; e-mail: jgonza@uaz.edu.mx; \\ hejunez@hotmail.com; anuard.pacheco@uaz.edu.mx; editholmostru@gmail.com; \\ baucap@uaz.edu.mx) \\ *Corresponding author \\ e-mail: hejunez@hotmail.com
}

(Received $15^{\text {th }}$ Nov 2016; accepted $7^{\text {th }}$ Mar 2017)

\begin{abstract}
Currently, human activities in ecosystems have led to adverse effects in aquifers, with the main consequences being the loss of vegetation and water availability. This paper presents a multi-criteria qualitative matrix which is developed to assign different values which estimate the potential of a specific land cover to be a groundwater recharge site. The matrix was coupled with a quantitative analysis of land cover changes in the Aguanaval aquifer, within the central zone of Zacatecas State, Mexico. Land cover changes were determined using four satellite images from 1986, 1992, 2002 and 2016. The results indicate that from 1986 to 2016 croplands and pasture increased by approximately 33,483 ha, but the most important change for croplands and pasture occurred between 2002 and 2016 with an increase of 31,607 ha; mixed forest land class occupied $16.49 \%$ in 1986, but an increase in the period from 1986 to 1992 reached $18.69 \%$ and decreased to $13.30 \%$ and $11.76 \%$ for 2002 and 2016, respectively. For the mixed rangeland covering $61.26 \%$ of the aquifer area, the major land cover in 1986 decreased substantially in 2016 reaching only $17.09 \%$ of total area. It was identified that the sites with a high recharge potential are located in the east and central-southeast and the medium recharge potential sites are located in the central part while the low potential sites are distributed to the north and southwest side of the aquifer.
\end{abstract}

Keywords: land cover/land use, GIS, multi-temporal analysis, image classification

\section{Introduction}

The vast majority of the global freshwater reserves are in aquifers and they provide drinking water to 25 percent of the world population. In many arid regions, aquifers are the only water source (Mata-González et al., 2012). Groundwater has become an indispensable natural resource for human survival in the context of changing climate and population growth (Panda and Kumar, 2011). It is also an important resource of the ecosystems and the uncontrolled and excessive use of groundwater for human activities can lead to the disruption of the ecological functions with deleterious effects (MataGonzález et al., 2012). Groundwater resources are diminishing in different parts of the world due to anthropogenic withdrawals that exceed the natural recharge (Panda and Kumar, 2011), and the impact intensifies the tension leading to deterioration and loss of natural and semi-natural environments and their associated ecosystem services value (Yirsaw, 2016). The degradation of ecosystems is one of the big environmental problems after the water shortages in arid areas. Recently, environmental policy has 
been determined with respect to groundwater not only as a resource but as a living ecosystem (Huang et al., 2013).

Due to the above details, it is important to recognize and understand land cover (biophysical attributes of the earth's surface) and land use (human purpose or intervention applied to these attributes) changes as the major ecological processes affecting and that are affected by the dynamic interaction of ecosystems (Ricca and Guagliardi, 2015) and in turn, the impact of the hydrological responses of a catchment by altering the partitioning of precipitation into different components of the hydrological cycle, such as interception, infiltration, runoff, evapotranspiration, and groundwater recharge rate (Aduah, 2015). Likewise, ecosystem services can be defined as the conditions, processes and components of the natural environment that provide tangible and intangible benefits for the maintenance and fulfillment of human life (Sherrouse et al., 2011). These include the services of extraction, where the water is pumped from the aquifers and is used for a variety of human needs (e.g. the supply for drinking and for the production of food), and those services that are non-extractive, whereby the water is left in the soil or in the dependent ecosystems that provide to soil humidity, and a flow base to streams and wetlands, in addition to opportunities for recreation (Knüppe and Pahl-Wostl, 2011). But they are affected by land use and land cover change (LULCC) and satellite remote sensing techniques has been applied extensively for monitoring actual and spatial changes in a variety of natural environments (Pullanikkatil et al., 2016).

Well recharge is a critical water cycle parameter that is used for the assessment, planning and management of groundwater resources. The conversion of forest into agricultural land and the improvement of pastures results in increased surface and subsurface drainage, and modifies groundwater recharge (Latifovic et al., 2010) as a vector for nutrients and contaminants from the land surface to underlying aquifers (Keese et al., 2005).Various different methods are available for estimating recharge and regional estimates of recharge also have been developed using a variety of approaches. It is noteworthy that climate, geomorphology, and land cover are important characteristics to consider when developing a model for recharge (Lorenz and Delin, 2007). Therefore, the rapid economic development and the accelerated urbanization in recent decades have resulted in the serious degradation of water resources ( $\mathrm{Su}$ et al., 2015) via urbanization, industrialization, and intensive agriculture that result in rapid landscape change with the loss of ecological capacities (Ricca and Guagliardi, 2015). Human activity is one of the major driving forces leading to changes in land cover characteristics and subsequently hydrologic processes (Bonansea, 2016).

The basic controls on diffuse groundwater recharge include climate, vegetation, soils, and topography. Diffuse recharge refers to areally distributed recharge derived from precipitation or irrigation and should be distinguished from focused or concentrated recharge in topographic depressions, such as streams, lakes, and playas (Keese et al., 2005). The preservation of the existing ecosystems that depend on groundwater and the renaturation of selected degraded areas are important elements in the majority of the strategies related to sustainable development and management of water resources (Krogulec and Zabłocki, 2015). According to the climatic conditions and the development policy posed to the State of Zacatecas, Mexico in particular for the central portion near the capital of the State, the use of groundwater for agricultural purposes and supply of the population is essential in sustaining economic development (NuñezPeña et al., 2015). Remote sensing (RS) and Geographic Information System (GIS) are 
now providing new tools for advanced ecosystem management, land-use mapping, and planning. The collection of remotely sensed data facilitates the synoptic analyses of Earth - system functions, patterning, and change at local, regional, as well as at global scales over time (Pullanikkatil et al., 2016). Classification of land cover and land use types has been one of the most widely adopted applications of satellite data ( $\mathrm{Li}$ et al., 2014). The analysis of satellite images to detect land cover/land use changes is based on the assumption that the recorded electromagnetic radiation, which is the basis of categorizing land covers, is altered as the land cover/land use of the same geographic area changes. Supervised classification systems can be grouped as either parametric or non-parametric methods. The parametric methods include maximum likelihood classification, which takes the variability of classes into account by using the covariance matrix which is important for understanding the current situation of the aquifer. Consequently the confusion matrix was used (Aduah, 2015) which is a common method for accuracy assessment via the use of an error matrix which can provide the detailed assessment of the agreement between the classified result and the reference data, and provide the information of how the misclassification occurred (Li et al., 2011).

In this article, the main aim is the classification of land use to note changes in land cover over different years of study (1986, 1992, 2002 and 2016) using Landsat data imagery, and also to identify the recharge areas through a comprehensive array of ecosystems and interactions with other factors considered such as: climatology, geology, edaphology, physiography and hydrogeochemistry that exist in the area of study. A multi-criteria qualitative matrix was developed in order to assign different values which estimate the potential of a specific land cover to be a groundwater recharge site.

\section{Materials and methods}

\section{Study Area (SA)}

The Aguanaval aquifer, in the central zone of Zacatecas State, Mexico, is located between longitudes $102^{\circ} 44^{\prime} \mathrm{W}$ and $103^{\circ} 24^{\prime} \mathrm{W}$ and latitudes $22^{\circ} 40^{\prime} \mathrm{N}$ and $23^{\circ} 41^{\prime} \mathrm{N}$ and mostly straddles two municipalities, namely Fresnillo and Sain Alto (Figure 1). The aquifer has a generally low relief, with the elevation ranging between 2,923 and 1,909 $\mathrm{m}$ above mean sea level (AMSL) and it has a superficial area of $2,835 \mathrm{Km}^{2}$. The rainfall ranges between 250 and $600 \mathrm{~mm}$ per annum and the annual average minimum and maximum temperatures are $-5.2{ }^{\circ} \mathrm{C}$ and $29.5{ }^{\circ} \mathrm{C}$, respectively. The predominant land cover consists of irrigated and seasonal croplands. The detailed geology of the aquifer can be found in Navarro-Solis et al. (2016). The soil is composed of Kastanozems, Phaeozems, Regosols and Lithosols according to the Food and Agricultural Organization (FAO) of the United Nations (UN) soil classification system. The major economic activity in the aquifer is the food crop production. 


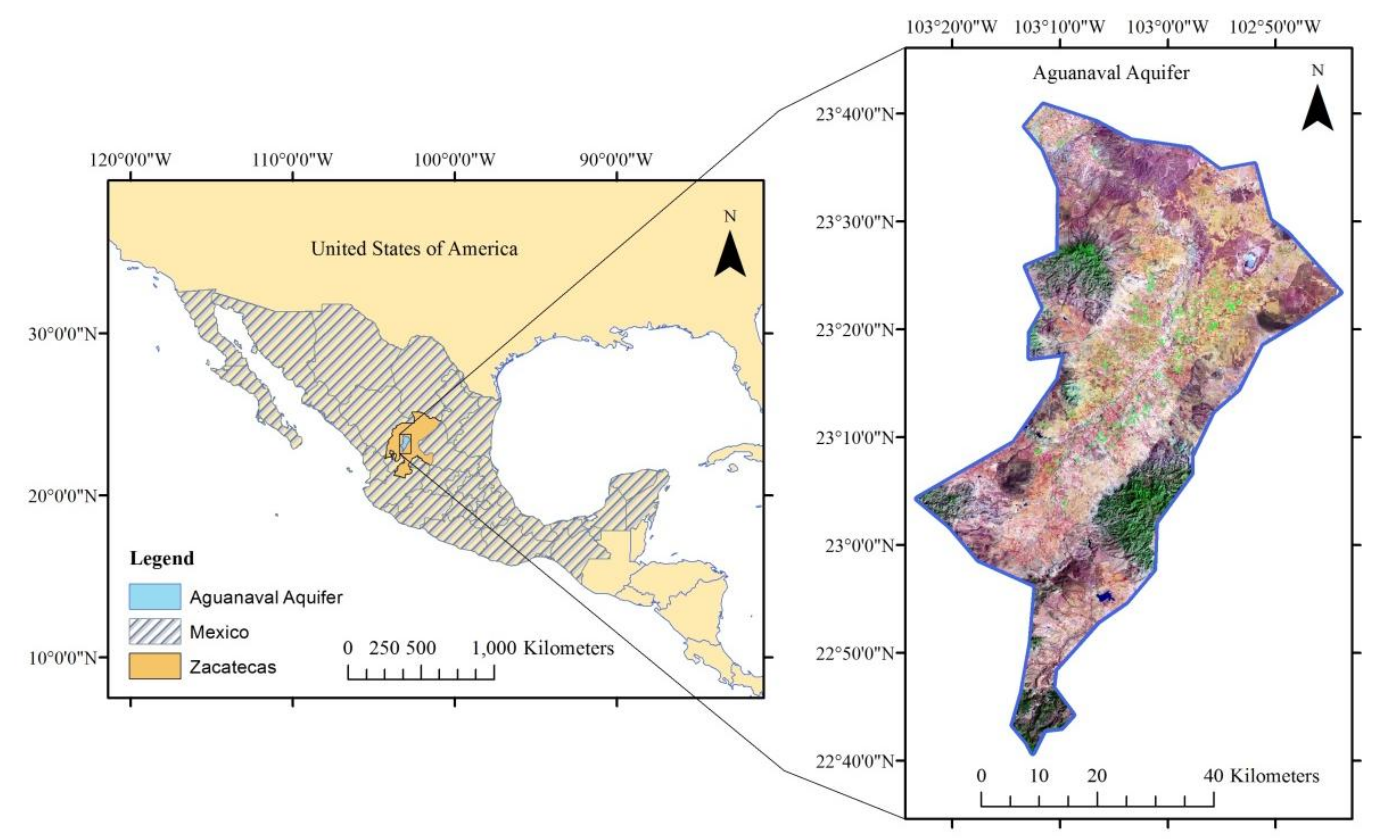

Figure 1. Location of the study area

\section{Data Acquisition and Pre-processing}

Cartography data for the study were obtained from the National Institute of Statistics and Geography (INEGI), and the boundary polygon was provided by the National Water Commission (CONAGUA, 2015) which are Mexican Government agencies dedicated to coordinating the national geographical information and the water administration, respectively. Four satellite images covering the period 1986 to 2016 were acquired from the United States Geological Survey (USGS, 2016) were also included (Table 1). Acquisition dates were selected in the same month to minimize seasonal vegetation differences. Local knowledge of the inhabitants of the sites over the aquifer was considered as field data. All the images were digitized and analyzed and the visualization and the preprocessing of spatial data were conducted by ArcGIS 10. Preprocessing consisted on geo-referencing the Landsat images to the UTM WGS84 Zone 13 North projection by the data suppliers, and all were matched with the official boundary polygon through an overlaying map tool. It was also necessary to implement a geometrical correction. All of the Landsat images are free of cloud or haze whereby the haze removal could improve the quality of image and helps in achieving a better classification of image. After Mustak et al. (2016), the NOAA National Geophysical Data Center, USA supplied freely available cloud-free annual composite of low resolution (GSD $2.7 \mathrm{Km}$ ) DMSP-OLS night times light (NTL) with 6 bits of data (DN 0 to 63) since year 1992 onwards. 
Table 1. Satellite images used for the study

\begin{tabular}{ccccc}
\hline Sensor & No. Bands & $\begin{array}{c}\text { Spatial } \\
\text { Resolution }(\mathbf{m})\end{array}$ & $\begin{array}{c}\text { Acquisition } \\
\text { Date }\end{array}$ & Source \\
\hline $\begin{array}{c}\text { Landsat legacy: } \\
\text { TM Mosaics } \\
\text { Landsat legacy: } \\
\text { L1-MSS }\end{array}$ & 4 & 28.50 & $01 / 1986$ & \\
$\begin{array}{c}\text { Landsat legacy: } \\
\text { L7 ETM+ SLC on } \\
\text { Landsat legacy: }\end{array}$ & 4 & 60.60 & $04 / 1992$ & USGS \\
L8 OLI/TIRS & 11 & 30.30 & $02 / 2002$ & \\
\hline
\end{tabular}

\section{Image Classification}

Image classification was carried out by generating spectral signatures, using samples created for each satellite image. The samples were created by selecting about $70 \%$ of the sample class data for each satellite image. Five thematic classes were selected to represent the land cover. The classes used are cropland and pasture, other agricultural land (fallow land and seasonal agriculture land), mixed forest land, mixed rangeland, and water according to the land cover classification system for use with remote sensor data (level II) presented in Anderson et al. (1976). Li et al. (2014) tested several algorithms to perform land cover classification; these authors recommend the use of the Maximum Likelihood Classifier (MLC) algorithm over other algorithms, such as Knearest neighbor (KNN), Logistic regression (LR), C4.5, Classification and Regression Tree, etc. However, there are image classification techniques which also report good results compared to MLC, such as Support vector machine (SVM) (Singh et al., 2013) or Artificial neural network (ANN) (Mas, 2004; Kavzoglu and Mather, 2003). The MLC algorithm was used to perform the final classification which is based on the probability of a pixel belonging to a specific class.

\section{Accuracy Assessment}

A common method to evaluate the performance of the classification algorithm is conducted by creating confusion matrices between the land cover maps and the test data, calculating assessment parameters, such as overall classification accuracy (OCA), producer's accuracy (PA), user's accuracy (UA), and overall kappa coefficient (OKC) (Congalton, 1991). OCA considers only the total number of correctly classified class without taking into account the omission and commission errors, therefore it does not reveal whether errors were evenly distributed between classes or whether some classes were really bad and some really good. The OKC is a measure of overall statistical agreement of an error matrix, which takes non-diagonal elements into account (Li et al, 2011). The kappa statistic was based on the formula provided by Congalton (1991) in Equation (1).

$$
K=\frac{N \sum_{i=1}^{r} x_{i i}-\sum_{i=1}^{r}\left(x_{i+} * x_{+i}\right)}{N^{2}-\sum_{i=1}^{r}\left(x_{i+} * x_{+i}\right)}
$$


where $r$ is the number of rows in the matrix, $x_{i i}$ is the number of observations in row $i$ and column $i, x_{i+}$ and $x_{+i}$ are the marginal totals of row $i$ and column $i$, respectively, and $N$ is the total number of observations.

\section{Delineation of Potential Sites of Groundwater Recharge}

A multi-criteria qualitative matrix was developed in order to assign different values which estimate the potential of a specific land cover to be a groundwater recharge site, and Dar et al. (2010) proposed the use of four qualitative values: good, moderate, poor and poor to moderate as groundwater potential zones; in our study we used three qualitative values: high $(\mathrm{H})$, medium $(\mathrm{M})$ and low $(\mathrm{L})$ as a recharge range. The matrix takes into account where the land cover zones (2016) overlap with other science criteria such as climatology, geology, edaphology, physiography and hydrogeochemistry in order to define the potential to recharge groundwater. To delineate the sites, several multidisciplinary studies were analyzed and their proposals for each of the criteria are explained below.

With respect to climatology, Kamp and Hayashi (2008) established that semiarid zones have a higher potential for evapotranspiration which is greater than precipitation. Formerly, for a precipitation event, the runoff amount will not be large enough to create intercommunicated pluvial networks. In geology, a previous research carried out by Wolaver et al. (2008) utilized the structure of sub-surface porosity materials in reference to groundwater flow patterns. They presented a generalized hydrostratigraphic table to estimate the recharge potential as a function of lithology features (Table 2).

Table 2. Generalized Hydrostratigraphy

\begin{tabular}{|c|c|c|}
\hline Class & Type & Recharge potencial \\
\hline \multirow{4}{*}{ Sedimentary } & Sandstone & Low \\
\hline & Limestone & Medium - Low \\
\hline & Conglomerate & Medium - Low \\
\hline & Sandstone-Lutites & Low \\
\hline \multirow{3}{*}{ Extrusive igneous } & Rhyolite porphyry & Low \\
\hline & Basic & Low \\
\hline & Acid & Low \\
\hline
\end{tabular}

Peñuela and Carrillo (2013) analyzed several soils in order to make an analysis about the relation between soils and recharge/discharge sites. They define the horizons as an important index of the features which allows a major approximation of the hydraulic soil behavior. The types of soils associated with recharge zones are: leptosol, calcareous and eutric regosol, humic and eutric cambisol, chromic and orthic luvisol, and possibly the subgroup, haplic phaozem. These soils were compared with the study site soils to be defined as being of high potential.

An investigation carried out by Bertrand et al. (2011) established three types of groundwater flow: (i) local systems are produced relatively close to the surface, such as a site with a higher elevation than an adjacent zone like a stream (typically from $100 \mathrm{~m}$ to $1 \mathrm{Km}$ scales); (ii) intermediate flow systems (one or more topography maximums and shallow zones can be situated between recharge and discharge sites); (iii) regional 
systems, these systems reach deeper, therefore these extents over greater distances than the other two. According to the aforementioned criteria, potential sites for groundwater recharge are: mountains and plateau landings which have a high potential for ecosystems such as forest and natural grasslands; for medium potential there are low hills and plains with mixed grasslands; urban areas and croplands in the lowest surface correspond to low potential.

Groundwater geochemistry evolution is useful for identifying flow patterns and potential recharge zones. The Chebotarev sequence was used to describe the geochemistry of water evolution from recharge zones to discharge zones $\left(\mathrm{HCO}_{3}{ }^{-}-\mathrm{SO}_{4}{ }^{2-}\right.$ - $\left.\mathrm{Cl}^{-}\right)$(Cámbara and Álvarez, 2012).

\section{Results}

The classification accuracies of the maps are presented in Table 3; Kappa values are acceptable and are comparable according to investigations carried out with similar methodology (Yuan et al., 2005; Shen et al., 2013; Li et al., 2014; Aduah et al., 2015). (Foody, 2002) explains how errors in accuracy affect classification and how one hundred percent of accuracy cannot be achieved, therefore a value of $99.9 \%$ was established instead. According to our knowledge, there are no similar investigations that were performed in northern Mexico. In Appendix A, the confusion matrices with reference data (No. of points) are presented.

Table 3. Summary of Landsat classification accuracies (\%) for 1986, 1992, 2002 and 2016

\begin{tabular}{lcccccccc}
\hline \multirow{2}{*}{ Land Cover } & \multicolumn{2}{c}{1986} & \multicolumn{2}{c}{1992} & \multicolumn{2}{c}{2002} & \multicolumn{2}{c}{2016} \\
\cline { 2 - 9 } & Producer's & User's & Producer's & User's & Producer's & User's & Producer's & User's \\
\hline Croplands and pasture & 98 & 87.5 & 97.78 & 99.9 & 99.99 & 99.9 & 99.9 & 90.91 \\
Mixed forest land & 88 & 99.9 & 96 & 90.56 & 86 & 87.55 & 88 & 78.57 \\
Mixed rangeland & 72 & 92.3 & 99.9 & 94.82 & 99.9 & 99.9 & 92 & 97.87 \\
Other agricultura land & 99.9 & 99.9 & 99.9 & 92.59 & 99.9 & 96.15 & 96 & 99.9 \\
Water & 92 & 75.4 & 82 & 99.9 & 84 & 85.71 & 72 & 81.81 \\
Overall accuracy & 90 & & 95.2 & & 94 & & 89.6 & \\
Kappa statistic & 87.5 & & 93.99 & & 92.5 & & 87 & \\
\hline
\end{tabular}

Classification maps were generated for all four years, Figure 2 shows the aquifer that is covered by five land cover classes: croplands and pasture, mixed forest land, mixed rangeland, other agricultural land and water; the individual land cover area and change statistics for the four years are summarized in Table 4. From 1986 to 2016 croplands and pasture increased by approximately 33,483 ha, but the most important change for croplands and pasture occurred between 2002 and 2016 with an increase of 31,607 ha because of all the wells that had been installed in this fourteen year period, with the main aim of groundwater extraction being to improve the food production in the aquifer. Between 1,000 and 1,500 wells were drilled, with an approximate density of one well per 20 ha. Wells are located in the alluvial plain (central and northern aquifers) (CONAGUA, 2011). Areal coverage by mixed forest land and mixed rangeland decreased between 1986 and 2016. 
Mixed forest land class occupied $16.49 \%$ in 1986, but increases in the period from 1986 to 1992 reaching $18.69 \%$ and decreased to $13.30 \%$ and $11.76 \%$ for 2002 and 2016, respectively. For the mixed rangeland covering $61.26 \%$ of the aquifer area, the major land cover in 1986 decreased substantially in 2016, reaching only $17.09 \%$ of total area. This change could be understood by analyzing another important change, the increase of other agriculture land; in 1986 other agriculture land represented $21.51 \%$ and reached $58.53 \%$ in 2016; in this period of 30 years mixed rangeland was occupied by other agricultural land. The percentage of water class, which is mainly water contained in reservoirs and a few lakes, represented for all four years less than $0.30 \%$ of the aquifer area, however, the small changes detected could be related with the varying annual rainfall rate and consequently the varying water levels in dams and bodies water. Low producer and user data accuracy of water use are located in the southeastern aquifer, where the mixed forest land has a high presence.

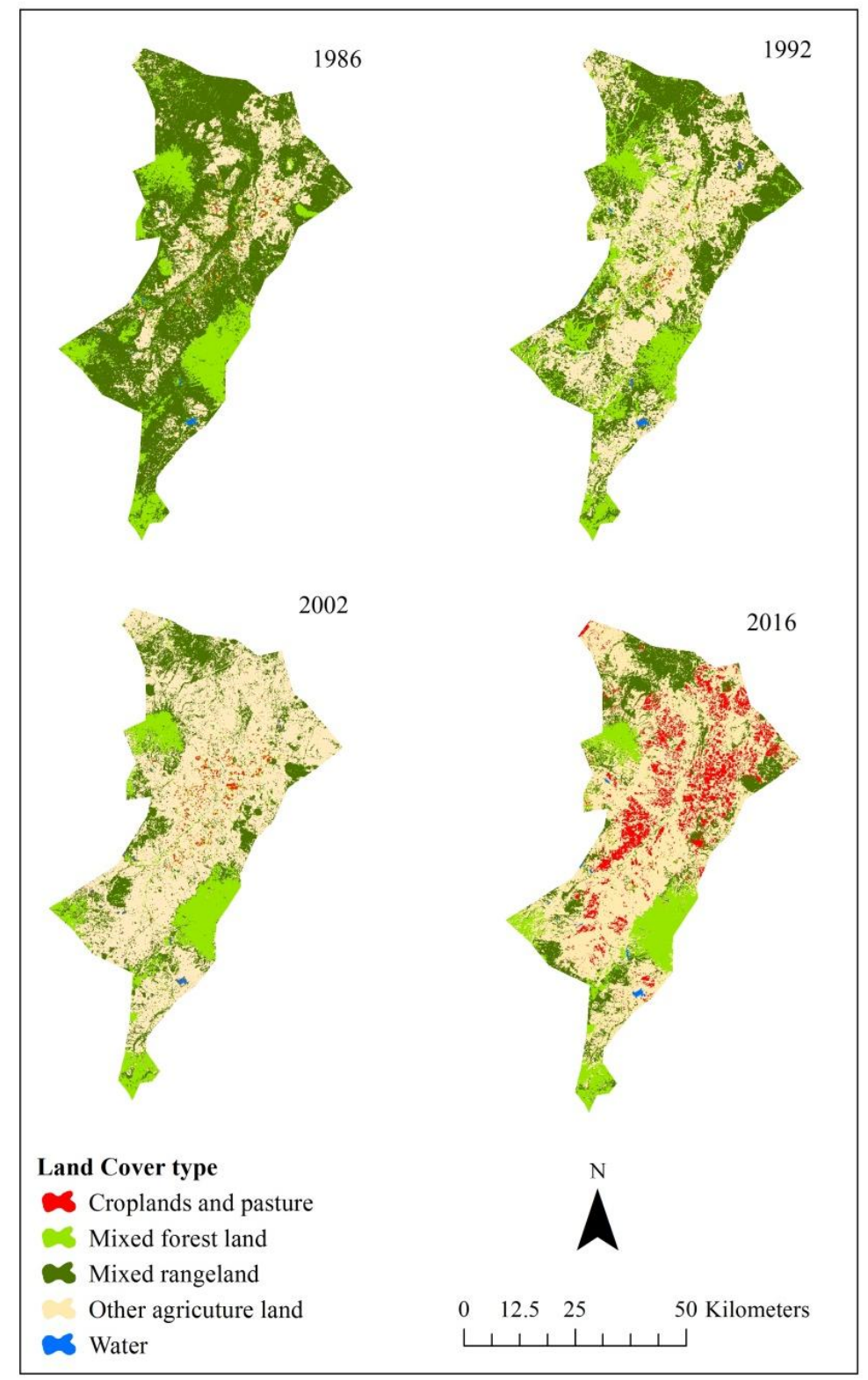

Figure 2. Maps of land cover changes in Aguanaval aquifer, 1986, 1992, 2002 and 2016 
Table 4. Summary of Landsat classification area statistics for 1986, 1992, 2002 and 2016

\begin{tabular}{lccccccccc}
\hline \multirow{2}{*}{ Land Cover } & \multicolumn{2}{c}{1986} & \multicolumn{2}{c}{1992} & \multicolumn{2}{c}{2002} & \multicolumn{2}{c}{2016} \\
\cline { 2 - 9 } & area (ha) & $\%$ & area (ha) & $\%$ & area (ha) & $\%$ & area (ha) & $\%$ \\
\hline Croplands and pasture & $1,543.37$ & $0.54 \%$ & $1,598.87$ & $0.56 \%$ & $3,418.99$ & $1.21 \%$ & $35,026.6$ & $12.35 \%$ \\
Mixed forest land & $46,769.18$ & $16.49 \%$ & $52,999.6$ & $18.69 \%$ & $37,718.38$ & $13.30 \%$ & $33,354.15$ & $11.76 \%$ \\
Mixed rangeland & $173,701.87$ & $61.26 \%$ & $104,612.04$ & $36.89 \%$ & $60,057.35$ & $21.18 \%$ & $48,459.37$ & $17.09 \%$ \\
Other agriculture land & $60,999.48$ & $21.51 \%$ & $123,620.74$ & $43.60 \%$ & $181,665.18$ & $64.07 \%$ & $165,961.04$ & $58.53 \%$ \\
Water & 536.31 & $0.19 \%$ & 718.96 & $0.25 \%$ & 690.31 & $0.24 \%$ & 749.05 & $0.26 \%$ \\
Total & $283,550.21$ & & $283,550.21$ & & $283,550.21$ & & $283,550.21$ & \\
\hline
\end{tabular}

To evaluate the results of land cover conversions, matrices of land cover changes from 1986 to 1992, 1992 to 2002, 2002 to 2016, and 1986 to 2016 were created (Table 5). In the table, percentages of unchanged area are located along the major diagonal of the matrix; the sum of the diagonal percentages for each matrix represents the total area of land cover that did not change between years. The off-diagonals show changes from one class to the other. The sum of the diagonal elements between 1986 and 1992 illustrates that $65.20 \%$ of the land cover did not change, compared to 52\% between 1992 and 2002 and $76 \%$ between 2002 and 2016. These results indicate major fluctuations between one land cover and others that occur most frequently between croplands and pastures and other agriculture land; this transition is most appreciable in Table 5d with a change range of around $10 \%$. Transition from mixed rangeland to other agriculture land was higher between 1992 and 2002 (13.60\%) than 2002 and 2016 (5.60\%) and between 1986 and 1992 (2\%). Besides water, mixed forest land did not have greater changes than $3 \%$, i.e. transition from mixed forest land to croplands and pasture between 1986 and 1992 was $1.2 \%$ while transition from mixed forest land to other agriculture land between 1992 and 2002 was $2.40 \%$. Classification errors may also cause unusual changes.

The interaction between land cover and other criteria suggest the potential sites of groundwater recharge in the Aguanaval aquifer (Figure 3).

A clear example of a potential high groundwater recharge zone is exemplified the relationship concerning mixed forest lands with sub-humid climatology. For a zone of potential medium there is the association between croplands and pasture with plains physiography and for a zone of low potential we note the interplay of mixed rangeland with a mixed sodium hydrogeochemical factor.

Table 5. Matrices of land cover changes (\%) from 1986 to 2016

\begin{tabular}{|c|c|c|c|c|c|c|}
\hline \multicolumn{7}{|c|}{ a. 1986 to 1992} \\
\hline & \multirow[b]{2}{*}{ Land cover } & \multicolumn{5}{|c|}{ From 1986} \\
\hline & & Water & $\begin{array}{c}\text { Mixed forest } \\
\text { land }\end{array}$ & $\begin{array}{l}\text { Croplands } \\
\text { and pasture }\end{array}$ & $\begin{array}{c}\text { Other } \\
\text { agriculture } \\
\text { land }\end{array}$ & $\begin{array}{l}\text { Mixed } \\
\text { rangeland }\end{array}$ \\
\hline \multirow{5}{*}{$\begin{array}{c}\text { To } \\
1992\end{array}$} & Water & $17.20 \%$ & $0.00 \%$ & $0.00 \%$ & $0.00 \%$ & $0.00 \%$ \\
\hline & Mixed forest land & $1.20 \%$ & $18.80 \%$ & $1.60 \%$ & $1.20 \%$ & $0.80 \%$ \\
\hline & Croplands and pasture & $1.60 \%$ & $1.20 \%$ & $1.20 \%$ & $0.80 \%$ & $0.00 \%$ \\
\hline & Other agriculture land & $0.00 \%$ & $0.00 \%$ & $14.00 \%$ & $10.80 \%$ & $2.00 \%$ \\
\hline & Mixed rangeland & $0.00 \%$ & $0.00 \%$ & $3.20 \%$ & $7.20 \%$ & $17.20 \%$ \\
\hline
\end{tabular}




\begin{tabular}{|c|c|c|c|c|c|c|}
\hline \multicolumn{7}{|c|}{ b. 1992 to 2002} \\
\hline & & \multicolumn{5}{|c|}{ From 1992} \\
\hline & Land Cover & $\begin{array}{l}\text { Croplands } \\
\text { and } \\
\text { pasture }\end{array}$ & $\begin{array}{c}\text { Other } \\
\text { agriculture } \\
\text { land }\end{array}$ & Water & $\begin{array}{l}\text { Mixed forest } \\
\quad \text { land }\end{array}$ & $\begin{array}{l}\text { Mixed } \\
\text { rangeland }\end{array}$ \\
\hline \multirow{5}{*}{$\begin{array}{c}\text { To } \\
2002\end{array}$} & Croplands and pasture & $2.40 \%$ & $1.60 \%$ & $0.00 \%$ & $0.00 \%$ & $0.00 \%$ \\
\hline & Other agriculture land & $16.40 \%$ & $14.00 \%$ & $2.40 \%$ & $2.80 \%$ & $13.60 \%$ \\
\hline & Water & $0.00 \%$ & $0.40 \%$ & $14.00 \%$ & $0.00 \%$ & $0.00 \%$ \\
\hline & Mixed forest land & $2.40 \%$ & $1.60 \%$ & $0.00 \%$ & $15.20 \%$ & $0.00 \%$ \\
\hline & Mixed rangeland & $0.80 \%$ & $2.40 \%$ & $1.60 \%$ & $2.00 \%$ & $6.40 \%$ \\
\hline \multicolumn{7}{|c|}{ c. 2002 to 2016} \\
\hline & & \multicolumn{5}{|c|}{ From 2002} \\
\hline & Land Cover & $\begin{array}{l}\text { Croplands } \\
\text { and } \\
\text { pasture }\end{array}$ & $\begin{array}{c}\text { Other } \\
\text { agriculture } \\
\text { land }\end{array}$ & $\begin{array}{l}\text { Mixed forest } \\
\quad \text { land }\end{array}$ & Water & $\begin{array}{l}\text { Mixed } \\
\text { rangeland }\end{array}$ \\
\hline \multirow{5}{*}{$\begin{array}{c}\text { To } \\
2016\end{array}$} & Croplands and pasture & $10.40 \%$ & $4.00 \%$ & $0.80 \%$ & $0.00 \%$ & $2.00 \%$ \\
\hline & Other agriculture land & $9.20 \%$ & $15.60 \%$ & $0.00 \%$ & $1.20 \%$ & $5.60 \%$ \\
\hline & Mixed forest land & $0.00 \%$ & $0.00 \%$ & $19.20 \%$ & $0.00 \%$ & $0.40 \%$ \\
\hline & Water & $0.00 \%$ & $0.00 \%$ & $0.00 \%$ & $18.80 \%$ & $0.00 \%$ \\
\hline & Mixed rangeland & $0.40 \%$ & $0.40 \%$ & $0.00 \%$ & $0.00 \%$ & $12.00 \%$ \\
\hline \multicolumn{7}{|c|}{ d. 1986 to 2016} \\
\hline & & \multicolumn{5}{|c|}{ From 1986} \\
\hline & Land Cover & $\begin{array}{l}\text { Croplands } \\
\text { and } \\
\text { pasture }\end{array}$ & $\begin{array}{c}\text { Other } \\
\text { agriculture } \\
\text { land }\end{array}$ & $\begin{array}{l}\text { Mixed forest } \\
\text { land }\end{array}$ & Water & $\begin{array}{l}\text { Mixed } \\
\text { rangeland }\end{array}$ \\
\hline \multirow{5}{*}{$\begin{array}{c}\text { To } \\
2016\end{array}$} & Croplands and pasture & $10.00 \%$ & $9.20 \%$ & $0.00 \%$ & $0.00 \%$ & $1.20 \%$ \\
\hline & Other agriculture land & $9.20 \%$ & $10.80 \%$ & $0.00 \%$ & $0.00 \%$ & $10.00 \%$ \\
\hline & Mixed forest land & $0.40 \%$ & $0.00 \%$ & $20.00 \%$ & $0.40 \%$ & $0.80 \%$ \\
\hline & Water & $0.00 \%$ & $0.00 \%$ & $0.00 \%$ & $19.60 \%$ & $0.00 \%$ \\
\hline & Mixed rangeland & $0.40 \%$ & $0.00 \%$ & $0.00 \%$ & $0.00 \%$ & $8.00 \%$ \\
\hline
\end{tabular}

For other interactions that are no less relevant refer to Table 6. In this way it has been identified that the sites with a high potential are located in the east and central-southeast.

The medium potential sites are located in the central part while the low potential sites are distributed to the north and southwest sides of the aquifer.

Table 6. Multi-criteria qualitative matrix (groundwater recharges potential sites)

\begin{tabular}{|c|c|c|c|c|c|c|}
\hline & & $\begin{array}{c}\text { Other } \\
\text { agriculture } \\
\text { land }\end{array}$ & $\begin{array}{c}\text { Croplands } \\
\text { and } \\
\text { pasture }\end{array}$ & $\begin{array}{l}\text { Mixed forest } \\
\text { land }\end{array}$ & $\begin{array}{l}\text { Mixed } \\
\text { rangeland }\end{array}$ & Water \\
\hline \multirow{2}{*}{$\begin{array}{l}\text { 흥 } \\
\frac{0}{0} \\
\frac{0}{\pi} \\
\frac{\underline{\sigma}}{0}\end{array}$} & $\begin{array}{l}\text { Semi-arid } \\
\text { temperate }\end{array}$ & L & $M$ & $\mathrm{H}$ & $M$ & $M$ \\
\hline & Sub-humid & L & $M$ & $\mathrm{H}$ & $\mathrm{M}$ & M \\
\hline \multirow{2}{*}{ 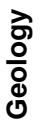 } & Fracture & M & $\mathrm{H}$ & $\mathrm{H}$ & $\mathrm{H}$ & $\mathrm{H}$ \\
\hline & Lithology & L & L & $M$ & L & L \\
\hline
\end{tabular}




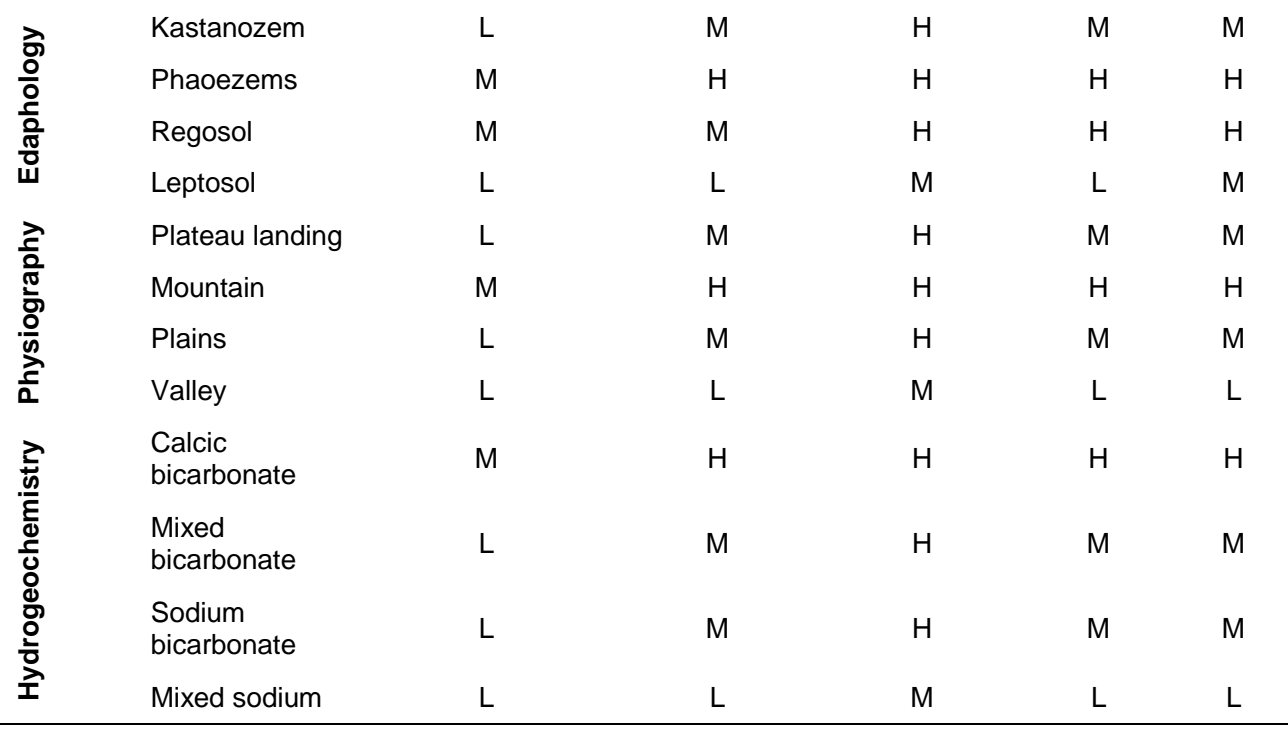

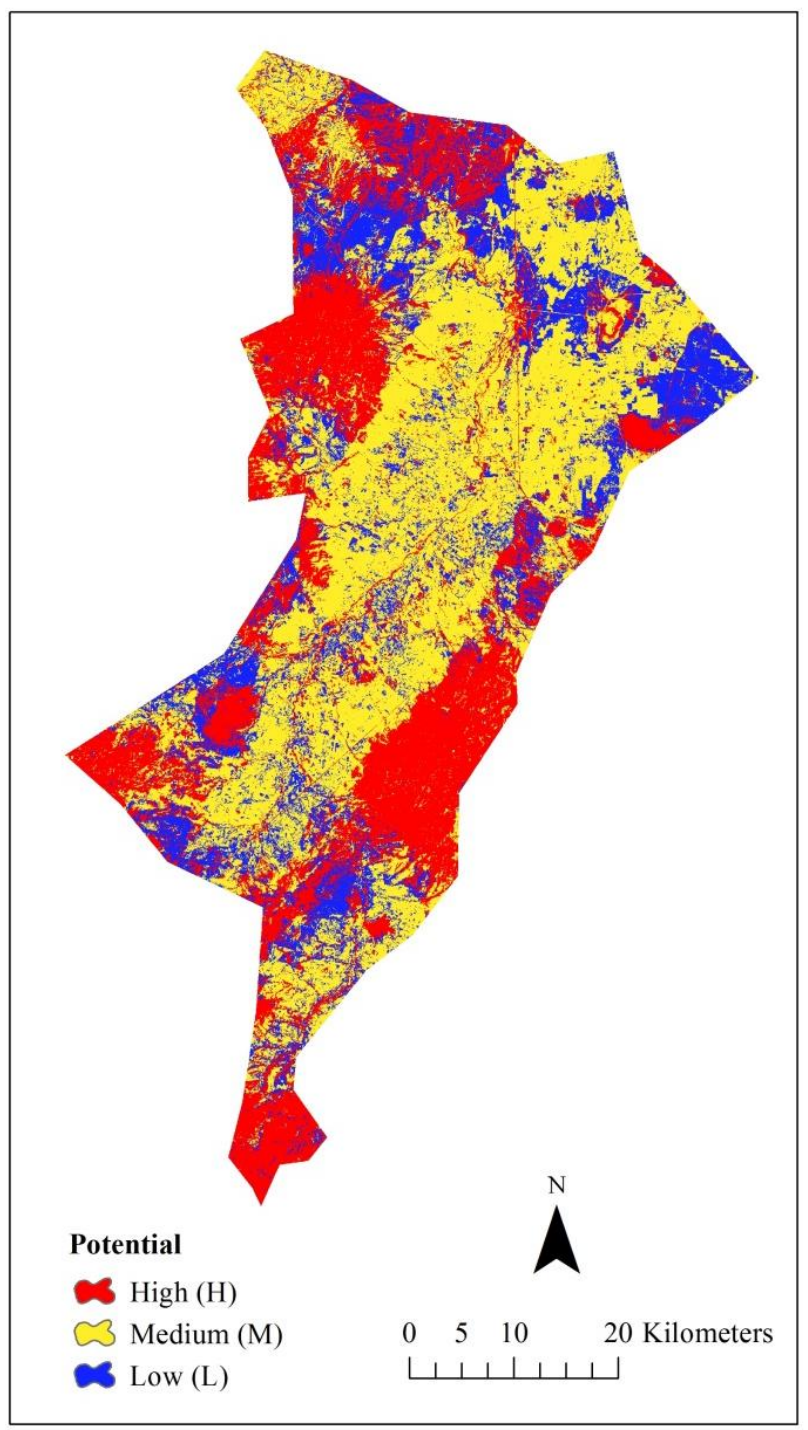

Figure 3. Map of potential groundwater recharge sites

APPLIED ECOLOGY AND ENVIRONMENTAL RESEARCH 15(3):387-402. http://www.aloki.hu • ISSN 15891623 (Print) • ISSN 17850037 (Online) DOI: http://dx.doi.org/10.15666/aeer/1503_387402 (c) 2017, ALÖKI Kft., Budapest, Hungary 


\section{Discussion}

As noted by Latifovic et al. (2010), the conversion of forests to agricultural land and induced pastures modifies the uptake of groundwater by the roots of plants through changes in transpiration rates. In addition, agriculture related to the change in land cover alters the quality of groundwater due to the application of various pesticides, fertilizers and animal wastes, all resulting in the modification of recharge rates, as shown by the results of this study which indicate that major fluctuations between one land cover and another occur most frequently between croplands and pastures and other agriculture land (Table 5d), where the change in the surface increase is observed, and this has produced significant damage to ecosystems. According to Gurnell et al. (2016), the presence of vegetation increases the infiltration of water (via roots) and decreases soil evaporation, which coincides with the research of Jinno et al. (2009), because as the urbanization stretches over increasingly larger areas, the ecological environment cannot be guaranteed. This is due to the areas of natural cover having mainly been replaced by crops. It is now widely recognized that global and local anthropogenic activities are deadly for groundwater-surfaces, and in particular for interfaces. Abundant urban pollutants, agriculture, industry, mining, road and tunnel construction, forestry, hydropower regulation, and sewerage have a pronounced impact on water systems (Bertrand et al., 2011). There are several examples in Mexico where the use of groundwater surpasses the superficial, especially in areas located in the central-north and north of the national territory (Peñuela and Carrillo, 2013).

\section{Conclusions}

The availability of groundwater that is produced in a given environment depends totally on the areas of recharge and discharge, which is why the multi-criteria matrix presented in this article is of great relevance for making decisions in the area as well as the being the basis for future research. Also, the map of groundwater recharges potential sites will be valuable in the planning of reforestation and sustainable decisions within the area.

The protection parameters and measures for the conservation and recovery of vegetation cover that can influence the recharge are recommended, and the scientific community is encouraged to carry out studies that integrate the ecology of the ecosystems as a means to understand the management of the groundwater and the management within aquifers. Currently, we see agricultural areas, urban areas, borders, where places of natural vegetation, places full of trees, shrubs, native grasses, i.e. ecosystems in balance. But, the emerging areas are soils where the underlying rock is not able to support the plants.

Understanding that ancient vegetation cover and its role in forest ecosystems, grasslands and scrublands (mainly) have disappeared from their original areas, shows that we have also lost functions, goods and services that are indispensable for the development and proper functioning of healthy ecosystems. Moreover, due to the global demand for water, the pressure for extraction and pollution is also increasing, therefore it is appropriate that the condition of the aquifer be considered in global water management policies. For being considered as a valuable resource of extraction of groundwater, the conservation of the aquifers and the biodiversity that exists in them is strongly encouraged. 
This research was part of an integral hydrogeological study that was carried out by the staff of the Engineering Academic unit of the Universidad Autónoma de Zacatecas, Mexico whose objective was to identify the groundwater flow systems in the Aguanaval aquifer, Mexico.

\section{REFERENCES}

[1] Aduah, M.S. (2015): Analysis Of Land Cover Changes in the Bonsa Catchment, Ankobra Basin, Ghana. - Appl. Ecol. Environ. Res. 13: 935-955.

[2] Anderson, J.R., Hardy, E.E., Roach, J.T., Witmer, R.E. (1976): A Land Use And Land Cover Classification System For Use With Remote Sensor Data. - Geological Survey Professional Paper 964.

[3] Bertrand, G., Goldscheider, N., Gobat, J.-M., Hunkeler, D. (2011): Review: From multiscale conceptualization to a classification system for inland groundwater-dependent ecosystems. - Hydrogeol. J. 20: 5-25.

[4] Bonansea, M. (2016): Assessing the impact of land use and land cover on water quaity in the watershed of a reservoir. - Appl. Ecol. Environ. Res. 14: 447-456.

[5] Cámbara, T.A.P., Álvarez, N.G. (2012): Hidroquímica del agua superficial de la subcuenca del río Quiscab, Guatemala.

[6] CONAGUA (2011): Levantamientos de aprovechamientos subtarraneos del acuifero Aguanaval: Informe tecnico. Comisión Nacional del Agua Subdirección General Técnica Gerencia de Aguas Subterráneas Subgerencia de Evaluación y Ordenamiento de Acuíferos.

[7] CONAGUA (2015): Determinación de la Disponibilidad de Agua en el Acuífero Aguanaval, Estado de Zacatecas. Comisión Nacional del Agua Subdirección General Técnica Gerencia de Aguas Subterráneas Subgerencia de Evaluación y Ordenamiento de Acuíferos.

[8] Congalton, R.G. (1991): A review of assessing the accuracy of classifications of remotely sensed data. - Remote Sens. Environ. 37: 35-46.

[9] Dar, I.A., Sankar, K., Dar, M.A. (2010): Remote sensing technology and geographic information system modeling: An integrated approach towards the mapping of groundwater potential zones in Hardrock terrain, Mamundiyar basin. - J. Hydrol. 394: 285-295.

[10] FAO Soil classification |FAO | Food and Agriculture Organization of the United Nations.

[11] Foody, G.M. (2002): Status of land cover classification accuracy assessment. - Remote Sens. Environ. 80: 185-201.

[12] Gurnell, A.M., Corenblit, D., García de Jalón, D., González del Tánago, M., Grabowski, R.C., O’Hare, M.T., Szewczyk, M. (2016): A Conceptual Model of Vegetationhydrogeomorphology Interactions Within River Corridors. - River Res. Appl. 32: 142163.

[13] Huang, T., Pang, Z., Chen, Y., Kong, Y. (2013): Groundwater circulation relative to water quality and vegetation in an arid transitional zone linking oasis, desert and river. Chin. Sci. Bull. 58: 3088-3097.

[14] INEGI: Instituto Nacional de Estadística y Geografía (INEGI).

[15] Jinno, K., Tsutsumi, A., Alkaeed, O., Saita, S., Berndtsson, R. (2009): Effects of land-use change on groundwater recharge model parameters. - Hydrol. Sci. J. 54: 300-315.

[16] Kamp, G. van der, Hayashi, M. (2008): Groundwater-wetland ecosystem interaction in the semiarid glaciated plains of North America. - Hydrogeol. J. 17: 203-214.

[17] Kavzoglu T., Mather P.M. (2003): The use of backpropagating artificial neural networks in land cover classification. International Journal of Remote Sensing 23: 4907-4938. 
[18] Keese, K.E., Scanlon, B.R., Reedy, R.C. (2005): Assessing controls on diffuse groundwater recharge using unsaturated flow modeling. - Water Resour. Res. 41, W06010.

[19] Knüppe, K., Pahl-Wostl, C. (2011): A Framework for the Analysis of Governance Structures Applying to Groundwater Resources and the Requirements for the Sustainable Management of Associated Ecosystem Services. - Water Resour. Manag. 25: 3387-3411.

[20] Krogulec, E., Zabłocki, S. (2015): Relationship between the environmental and hydrogeological elements characterizing groundwater-dependent ecosystems in central Poland. - Hydrogeol. J. 23: 1587-1602.

[21] Latifovic, R., Pouliot, D., Nastev, M. (2010): Earth Observation Based Land Cover for Regional Aquifer Characterization. Can. Water Resour. - J. Rev. Can. Ressour. Hydr. 35: 433-450.

[22] Li, C., Wang, J., Wang, L., Hu, L., Gong, P. (2014): Comparison of Classification Algorithms and Training Sample Sizes in Urban Land Classification with Landsat Thematic Mapper Imagery. - Remote Sens. 6: 964-983.

[23] Li, G., Lu, D., Moran, E., Hetrick, S. (2011): Land-cover classification in a moist tropical region of Brazil with Landsat TM imagery. - Int. J. Remote Sens. 32: 8207-8230.

[24] Lorenz, D.L., Delin, G.N. (2007): A Regression Model to Estimate Regional Ground Water Recharge. - Ground Water 45: 196-208.

[25] Mas, J.F. (2003): Mapping land use/cover in a tropical coastal area using satellite sensor data, GIS and artificial neural networks. - Estuarine, Coastal and Shelf Science 5:219230.

[26] Mata-González, R., McLendon, T., Martin, D.W., Trlica, M.J., Pearce, R.A. (2012): Vegetation as affected by groundwater depth and microtopography in a shallow aquifer area of the Great Basin. - Ecohydrology 5: 54-63.

[27] Mustak, S., Baghmar, N. K., Srivastava, P.K., Singh, S.K., Binolakar, R. (2016): Delineation and classification of rural-urban fringe using geospatial technique and onboard DMSP-Operational Linescan System. - Geocarto International 1-37.

[28] Navarro- Solis, O, Gonzalez-Trinidad, Junez-Ferreira, H.E, Cardona, A, and BautistaCapetillo, C.F (2016): Integrative Methodology for the Identification of Groundwater Flow Patterns: Aplication in a Semi-Arid Region of Mexico. - Appl. Ecol. Environ. Res. 14: 645-666.

[29] Nuñez-Peña, E.P., Escalona-Alcázar, F. de J., Bluhm-Gutiérrez, J., Cruz, R.-D. la, Alfonso, G., Torre-Guerrero, A. de la, Ortega-Martínez, E., Cardona-Benavides, A. (2015): Caracterización hidrogeoquímica del acuífero Jerez, estado de Zacatecas, México. - Tecnol. Cienc. Agua 6: 105-124.

[30] Panda, D.K., Kumar, A. (2011): Evaluation of an over-used coastal aquifer (Orissa, India) using statistical approaches. - Hydrol. Sci. J. 56: 486-497.

[31] Peñuela Arévalo, L.A., Carrillo Rivera, J.J. (2013): Definición de zonas de recarga y descarga de agua subterránea a partir de indicadores superficiales: Centro-Sur de la mesa central, México. - Investig. Geográficas 0.

[32] Pullanikkatil, D., Palamuleni, L.G., Ruhiiga, T.M. (2016): Land use/land cover change and implications for ecosystems services in the Likangala River Catchment, Malawi. Phys. Chem. Earth Parts ABC 93: 96-103.

[33] Ricca, N., Guagliardi, I. (2015): Multi-temporal dynamics of land use patterns in a site of community importance in southern Italy. - Appl Ecol Env. Res. 13: 677-691.

[34] Shen, Z., Lu, C., Yin, R., Qi, J. (2013): Land cover changes in northeast China from the late 1970s to 2004. - Appl. Ecol. Environ. Res. 11: 67-78.

[35] Sherrouse, B.C., Clement, J.M., Semmens, D.J. (2011): A GIS application for assessing, mapping, and quantifying the social values of ecosystem services. - Appl. Geogr. 31: $748-760$. 
[36] Singh, S.K., Srivastava, P.K., Gupta, M., Thakur, J.K., Mukherjee, S. (2014): Appraisal of land use/land cover of mangrove forest ecosystem using support vector machine. Enviromental Earth Science 71:2245.

[37] Su, Z.H., Lin, C., Ma, R.H., Luo, J.H., Liang, Q.O. (2015): Effect of land use change on lake water quality in different buffer zones. - Appl. Ecol. Environ. Res. 13: 639-653.

[38] USGS (2016): EarthExplorer.

[39] Wolaver, B.D., Sharp, J.M., Rodriguez, J.M., and Ibarra Flores, J.C. (2008): Delineation of Regional Arid Karstic Aquifers: An Integrative Data Approach. - Ground Water 46: 396-413.

[40] Yirsaw, E. (2016): Effect of temporal Land Use/Land Cover Changes on Ecosystems Services Value in Coastal Area of China: The case of Su -Xi-Chang Region. - Appl. Ecol. Environ. Res. 14: 409-422.

[41] Yuan, F., Sawaya, K.E., Loeffelholz, B.C., Bauer, M.E. (2005): Land cover classification and change analysis of the Twin Cities (Minnesota) Metropolitan Area by multitemporal Landsat remote sensing. - Remote Sens. Environ. 98: 317-328. 
APPENDIX A.

1A. Confusion Matrix for 1986 land cover map

\begin{tabular}{|c|c|c|c|c|c|c|}
\hline \multicolumn{7}{|c|}{ Reference Data (No. of points) } \\
\hline Land Cover & $\begin{array}{c}\text { Mixed } \\
\text { Forest } \\
\text { Land }\end{array}$ & $\begin{array}{c}\text { Croplands and } \\
\text { Pasture }\end{array}$ & $\begin{array}{l}\text { Other agriculture } \\
\text { land }\end{array}$ & Water & $\begin{array}{c}\text { Mixed } \\
\text { Rangeland }\end{array}$ & Ground Truth \\
\hline Mixed Forest Land & 49 & 6 & 0 & 0 & 1 & 56 \\
\hline Croplands and Pasture & 0 & 44 & 0 & 0 & 0 & 44 \\
\hline Other agriculture land & 0 & 0 & 36 & 0 & 3 & 39 \\
\hline Water & 0 & 0 & 0 & 50 & 0 & 50 \\
\hline Mixed Rangeland & 1 & 0 & 14 & 0 & 46 & 61 \\
\hline Total & 50 & 50 & 50 & 50 & 50 & 250 \\
\hline
\end{tabular}

1B. Confusion Matrix for 1992 land cover map

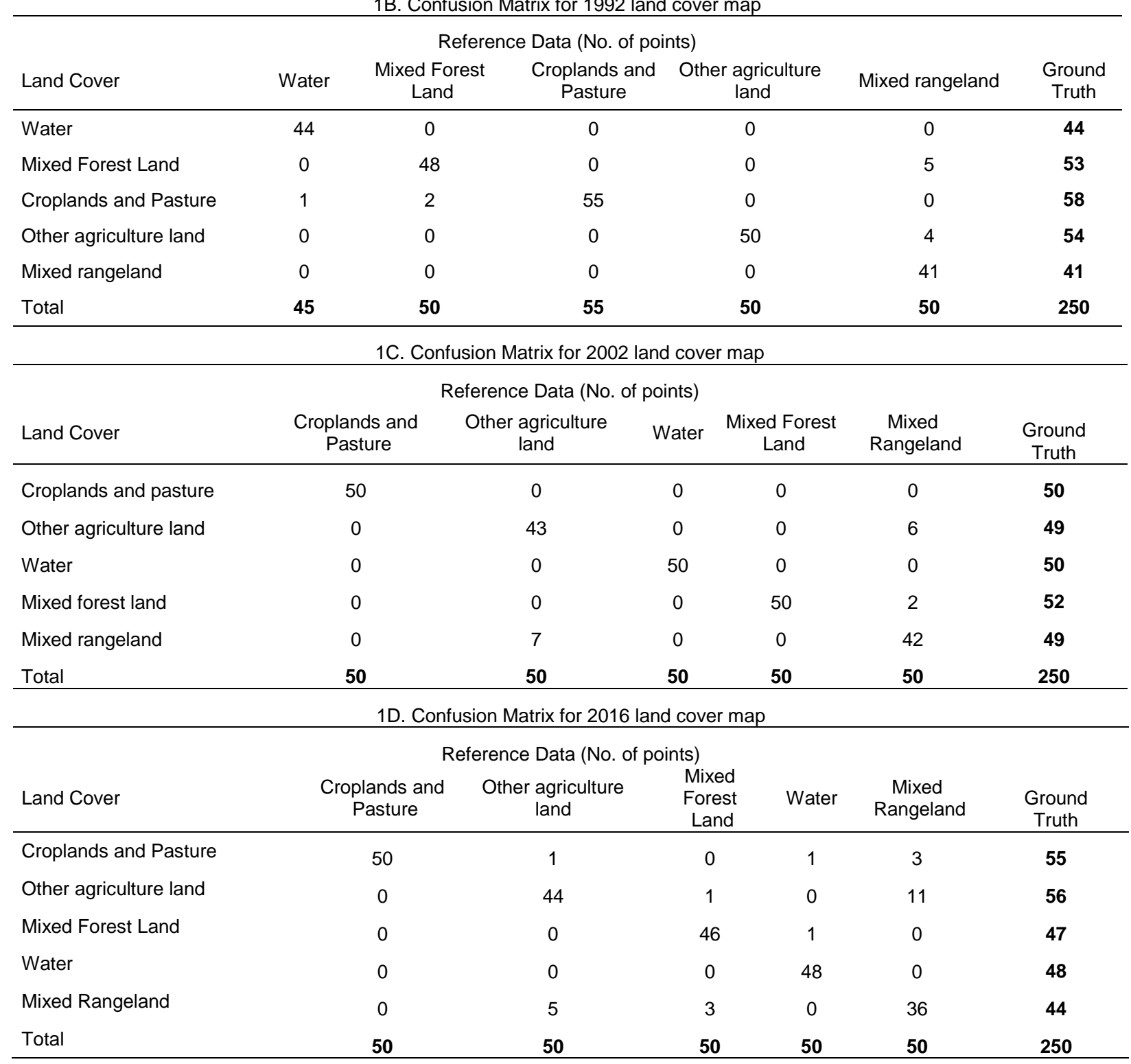

